\title{
Inoculation of Wheat With Azospirillum spp.: A Comparison Between Foliar and In-furrow Applications
}

\author{
L. V. Correia ${ }^{1}$, P. H. Felber ${ }^{1}$, L. C. Pereira ${ }^{1}$, A. L. Braccini ${ }^{1}$, D. U. Carvalho ${ }^{2}$, M. A. da Cruz $^{2}$, T. C. Matera ${ }^{1}$, \\ R. C. Pereira ${ }^{1}$, R. F. Santos ${ }^{1}$, D. C. V. Marteli ${ }^{1}$ \& E. A. F. Osipi ${ }^{3}$ \\ ${ }^{1}$ Universidade Estadual de Maringá, Maringá, PR, Brazil \\ ${ }^{2}$ Universidade Estadual de Londrina, Londrina, PR, Brazil \\ ${ }^{3}$ Universidade Estadual do Norte do Paraná, Bandeirantes, PR, Brazil \\ Correspondence: L. V. Correia, Department of Agronomy, Universidade Estadual de Maringá, Av. Colombo, \\ 5790, Maringá, PR, Brazil. E-mail: larissa.vinis@gmail.com
}

Received: September 19, 2019

Accepted: November 3, 2019 Online Published: December 15, 2019

doi:10.5539/jas.v12n1p194

URL: https://doi.org/10.5539/jas.v12n1p194

The research is financed by the CAPES (Brazil).

\begin{abstract}
The present work aimed to evaluate the agronomic performance of wheat grown under no-tillage system and submitted to different doses and methods of inoculation with Azospirillum spp. Eight treatments were tested: 1) control; 2) half $\mathrm{N}$ dose; 3) full dose of $\mathrm{N}$; 4) half $\mathrm{N}$ dose + standard seed inoculation (200 $\left.\mathrm{mL} \mathrm{ha}^{-1}\right)$; 5) half $\mathrm{N}$ dose + in-furrow inoculation $\left.\left(200 \mathrm{~mL} \mathrm{ha}^{-1}\right) ; 6\right)$ half $\mathrm{N}$ dose + in furrow inoculation $\left.\left(300 \mathrm{~mL} \mathrm{ha}^{-1}\right) ; 7\right)$ half $\mathrm{N}$ dose + inoculation by foliar spraying $\left(200 \mathrm{~mL} \mathrm{ha}^{-1}\right)$ and 8$)$ half $\mathrm{N}$ dose + inoculation by foliar spraying $\left(300 \mathrm{~mL} \mathrm{ha}^{-1}\right)$. The following parameters were evaluated: number of tillers per plant, number of grains per spike, shoot dry biomass, thousand seed mass, hectoliter weight, nitrogen content in grains and in shoot dry matter as well as crop yield. Our results showed that the supply of the half dose of mineral $\mathrm{N}$ associated to foliar inoculation with Azospirillum at the dose of $300 \mathrm{~mL} \mathrm{ha}^{-1}$ provided positive results on wheat yield, confirming the bacterial ability to fix $\mathrm{N}$. However, only the full mineral $\mathrm{N}$ fertilization stood out as the best $\mathrm{N}$ fertilization management.
\end{abstract}

Keywords: Triticum aestivum, fertilization, nitrogen fixation, yield

\section{Introduction}

Over the last decade, Brazil has imported aproximatlly half of its domestic wheat (Triticum aestivum) demand (CONAB, 2019a). To improve crop cultivation competitiveness against other winter crops such as corn, a more cost-effective fertizantion is pointed out as a crop management obstacle to improve wheat profitability, specially regarding nitrogen $(\mathrm{N})$, the country's most yield-limiting nutrient (Hungria et al., 2005) whose formulation relies on the importation of raw materials (CONAB, 2019b).

In soil, less than half of the $\mathrm{N}$ fertilizer applied to fields turns out to be available to plants, as $\mathrm{N}$ undergoes several loss processes, such as mineralization, immobilization, leaching and volatilization (Deuner et al., 2008). However, over the last 40 years, a wide array of investigations have confirmed the potential of the free-living bacteria Azospirillum spp. as fertilizer that, besides N fixation (Dobereiner \& Day, 1976; Hungria et al., 2010) is also able to promote plant growth trough the production of phythormones (Dobbelaer et al.,1999; Fukami et al., 2018). In fact, wheat and corn management based on partial mineral $\mathrm{N}$ fertilization coppled with Azospirillum inoculation has shown to be able meet the entire $\mathrm{N}$ requirement of these crops (Hungria et al., 2010; Cunha \& Caierão, 2014; Marks et al., 2015).

As a phytosanitary strategy, oftentimes wheat seeds are treated prior sowing with plant protection products that, in the case of soybean, have shown to be harmful to the survival of the N-fixer bacteria Bradyrhizobium spp. (Campo et al., 2009). Although it has been poorly investigated; this toxicity is also likely to be found in the case of Azospirillum spp. In this context, besides the standard seed and in-furrow applications, as free-living bacteria Azospirillum spp. can theoretically further be explored through foliar sprayings (Fukami et al., 2018). This has 
already been investigated by Fukami et al. (2016), who reported that both foliar and the in-furrow bacterial applicattions were as effective as standard seed inoculation to provide wheat with $\mathrm{N}$.

In the Brazilian Paraná state, the main country's region of wheat production (CONAB, 2019a), this crop is cultivated under no-tillage system in succettion to soybean harvesting, conditions in which almost no work with Azospirillum has been carried out. Therefore, there is a need for further studies aiming at investigating inoculation methods that, compared to seed inoculation, minimize or avoid the direct contact between plant protection products and bacterial inoculum. In this sense, this study particularly addressed the efficiency of foliar and in-furrow inoculation of wheat grown in a field rich in soybean residues that, as organic matter, act as $\mathrm{N}$ source, nutrient whose availability may impair the bacterial $\mathrm{N}$ fixation.

\section{Material and Methods}

The experiment was carried out at the institution experimental station (Lat. $23^{\circ} 02^{\prime} \mathrm{S}$, Long. $52^{\circ} 04^{\prime} \mathrm{W}$, and Alt. $509 \mathrm{~m}$ ) of the Universidade Estadual de Maringá (UEM), Maringá-PR, southern Brazil. The soil type of the area is classified as dystroferric Red Argisol (Embrapa, 2018) and had previously been cultivated with soybean. The results of the chemical analysis in the $0-20 \mathrm{~cm}$ layer prior installation was: $\mathrm{pH}\left(\mathrm{CaCl}_{2}\right)=4.88$, $\mathrm{P}(\mathrm{Mehlich}-1$ extraction) $=5.17 \mathrm{mg} \mathrm{dm}^{-3}, \mathrm{H}^{+}+\mathrm{Al}^{3+}=4.43 \mathrm{cmolc} \mathrm{dm}^{-3}, \mathrm{Al}^{3+}=0.0 \mathrm{cmolc} \mathrm{dm}^{-3}, \mathrm{~K}^{+}=0.13 \mathrm{cmolc} \mathrm{dm}^{-3}, \mathrm{Ca}^{2+}=$ $2.75 \mathrm{cmolc} \mathrm{dm}^{-3}, \mathrm{Mg}^{2+}=1.73 \mathrm{cmolc} \mathrm{dm}^{-3}, \mathrm{CTC}(\mathrm{T})=9.04 \mathrm{cmolc} \mathrm{dm}^{-3}$ and $\mathrm{BS}=51 \%$. The soil texture of the same layer was as follow: $52 \%$ of sand, $3 \%$ of silt and $45 \%$ of clay.

The area is located under the Köppen a Cfa climate (humid subtropical) according to IAPAR (2018). The data from rainfall and maximum and minimum temperatures recorded by the in-site metheorological station over the crop cycle are resumed in the Figure 1.

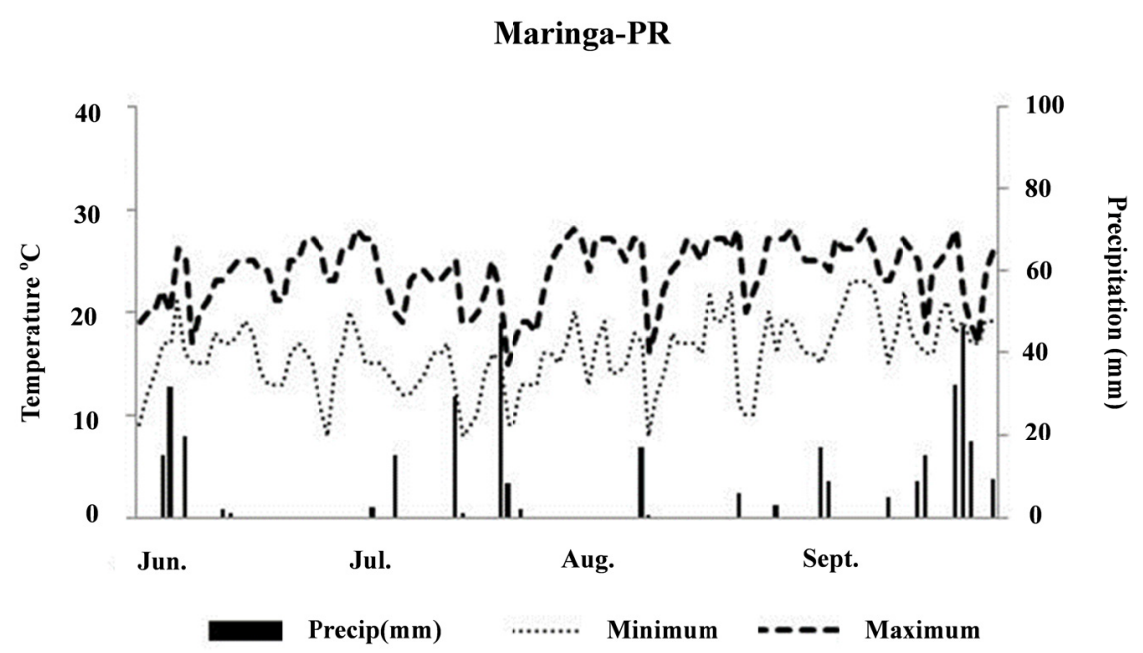

Figure 1. Summary of daily climatic data of rainfall and maximum and minimum temperatures over crop cycle (from June to September 2014). UEM's experimental station, Maringa-PR, Brazil

Adopting the no-tillage system, wheat cultivar CD 116 was sowed at the density of 420 viable seeds $\mathrm{m}^{-2}$. Based on soil analysis, the crop fertilization and phytosanitary management were performed according to Cunha and Caierão (2014). The treatments consisted of the combination between two doses of inoculant and two methods of application as schemed in Table 1. Three other treatments were performed as comparison: the first was conducted without either $\mathrm{N}$ fertilizer or inoculant, the second consisted of half of the recommended $\mathrm{N}$, wheareas the third received the entire $\mathrm{N}$ input. Splitted one-third at sowing and the remaining at crop tillering, urea ( $46 \%$ of $\mathrm{N}$ ) was used as mineral fertilizer, while a liquid formulation containg the A. brasilense AbV5 and AbV6 strains (concentration of $2 \times 10^{8} \mathrm{CFU} \mathrm{mL}^{-1}$ ) was adopted as inoculant. 
Table 1. Scheme of the treatments summarizing $\mathrm{N}$ fertilizer rates, A. brasilense doses and methods of applications in wheat cv. CD116

\begin{tabular}{llll}
\hline Treatment & $\begin{array}{l}\text { Mineral N fertilization } \\
\left(\mathrm{kg} \mathrm{ha}^{-1}\right)\end{array}$ & $\begin{array}{l}\text { Doses of inoculant } \\
\left(\mathrm{mL} \mathrm{ha}^{-1} / 100 \mathrm{~kg}^{-1} \text { seeds }\right)\end{array}$ & Methods of inoculation \\
\hline 1 & 0 & 0 & - \\
2 & 55 & 0 & - \\
3 & 110 & 0 & - \\
4 & 55 & 200 & Seed applicattion $^{1}$ \\
5 & 55 & 200 & In-furrow $^{2}$ \\
6 & 55 & 300 & In-furrow $^{2}$ \\
7 & 55 & 200 & Foliar spraying \\
8 & 55 & 300 & Foliar spraying \\
\hline
\end{tabular}

Note. ${ }^{1}$ Seed coating using $200 \mathrm{~mL} 100 \mathrm{~kg}^{-1} ;{ }^{2}$ Slurry volume of $50 \mathrm{~L} \mathrm{ha}^{-1} ;{ }^{3}$ Slury volume of $150 \mathrm{~L} \mathrm{ha}^{-1}$.

The experiment was performed in a completely randomized block design with eight treatments and four replications. Each plot was composed by 10 rows of $5.0 \mathrm{~m}$ length, spaced $0.16 \mathrm{~m}$ apart. At harvest, two outer lines were removed, as well as $0.5 \mathrm{~m}$ from each row end. Only plants from the six central rows of each experimental unit were evaluated, totalizing a useful area of $3.84 \mathrm{~m}^{2}$. The variables analyzed were as follows:

Shoot dry biomass: It was determined at the beginning of the flowering stage by randomly collecting 10 plants from the useful area of each plot. After dried in a forced air oven at $65^{\circ} \mathrm{C}$ until constant weight, the biomasses were weighted and the results were expressed as the average of 10 plants.

Number of tillers per plant: 10 plants per plot were evaluated at the begging of the boot stage.

Numbers of grains per spike: It was determined by collecting 10 spikes per plot at the crop complete maturation stage.

Crop yield: It was obtained from the grain mass harvested from the useful area of each plot. Yield was expressed in $\mathrm{kg} \mathrm{ha}^{-1}$ at $13 \%$ of moisture (Brasil, 2009).

Thousand seed mass: It was performed by weighing eight subsamples of 100 seeds for each replication according to Brasil (2009).

Hectoliter weight: It was determined by weighing a known volume $(225 \mathrm{~mL})$ of grains in a portable hectoliter device (Agrologic Al-101 ${ }^{\circledR}$ ). The results were expressed in $\mathrm{kg} \mathrm{hL}^{-1}$ (Brasil, 2009).

Nitrogen content in the shoot and grains: It was performed applying the Kjeldahl method (AOAC, 2010) to the samples collected to evaluate shoot dry biomass and yield, respectively.

Statistical analysis: All data were tested for residual homoscedasticity and normality and submitted to analysis of variance. When significant, means were compared by Duncan's test $(\mathrm{p} \leq 0.05)$ to identify pair of means and determine the significant differences between them (SAS, 2014).

\section{Results and Discussion}

The analysis of variance showed that $\mathrm{N}$ fertilization combined with Azospirillum spp. significantly altered wheat shoot dry biomass (SDB), $\mathrm{N}$ content in dry shoot (NCDS), $\mathrm{N}$ content in grains (NCG) as well as crop yield (CY). On the other hand, the number of tillers per plant (NTP), number of grains per spike (NGS), hectoliter weight (HW) and thousand seeds mass (TSM) were not significantly affected by the treatments described in Table 2 . 
Table 2. Mean values of number of tillers per plant (NTP), number of grains per spike (NGS), hectolitric weight (HW), shoot dry biomass (SDW), thousand seeds mass (TSM), N content in dry shoot (NCDS), N content in seeds (NCG) and crop yield (CY) of wheat cv. CD116, in response to different methods and doses of inoculant. Maringá-PR, Brazil

\begin{tabular}{lllll}
\hline Treatments & NTP & NGS & HW $\left(\mathrm{kg} \mathrm{hL}^{1}\right)$ & SDW $\left(\mathrm{g} \mathrm{plant}^{1}\right)$ \\
\hline 1 & $2.84^{\mathrm{ns}}$ & $41.60^{\mathrm{ns}}$ & $78.35^{\mathrm{ns}}$ & $0.863 \mathrm{~b}$ \\
2 & 2.95 & 42.60 & 78.60 & $0.933 \mathrm{~b}$ \\
3 & 2.75 & 42.50 & 78.65 & $1.425 \mathrm{a}$ \\
4 & 2.65 & 42.50 & 78.33 & $0.923 \mathrm{~b}$ \\
5 & 2.90 & 42.50 & 78.58 & $0.808 \mathrm{~b}$ \\
6 & 2.80 & 42.50 & 78.41 & $1.163 \mathrm{ab}$ \\
7 & 2.62 & 42.50 & 78.40 & $0.905 \mathrm{~b}$ \\
8 & 2.68 & 42.50 & 78.50 & $1.185 \mathrm{ab}$ \\
\hline $\mathrm{CV}(\%)$ & 22.7 & 8.5 & 2.3 & 24.9 \\
\hline Treatments & TSM $(\mathrm{g})$ & NCDS (mg N plant & NCG $\left(\mathrm{kg} \mathrm{N} \mathrm{ha}{ }^{1}\right)$ & $\mathrm{CY}\left(\mathrm{kg} \mathrm{ha}{ }^{1}\right)$ \\
\hline 1 & $40.61^{\mathrm{ns}}$ & $3.858 \mathrm{~b}$ & $49.93 \mathrm{~d}$ & $2411.31 \mathrm{~d}$ \\
2 & 40.51 & $5.193 \mathrm{a}$ & $57.82 \mathrm{c}$ & $2481.01 \mathrm{~cd}$ \\
3 & 40.48 & $5.338 \mathrm{a}$ & $113.51 \mathrm{a}$ & $3410.56 \mathrm{a}$ \\
4 & 40.19 & $5.598 \mathrm{a}$ & $56.68 \mathrm{c}$ & $2553.29 \mathrm{c}$ \\
5 & 40.39 & $6.818 \mathrm{a}$ & $55.24 \mathrm{~cd}$ & $2477.81 \mathrm{~cd}$ \\
6 & 40.47 & $6.118 \mathrm{a}$ & $68.06 \mathrm{~b}$ & $2494.63 \mathrm{~cd}$ \\
7 & 40.59 & $5.663 \mathrm{a}$ & $56.59 \mathrm{~cd}$ & $2490.25 \mathrm{~cd}$ \\
8 & 41.00 & $6.933 \mathrm{a}$ & $70.00 \mathrm{~b}$ & $2665.63 \mathrm{~b}$ \\
\hline CV $(\%)$ & 2.4 & 16.3 & 3.1 & 9.9 \\
\hline
\end{tabular}

Note ${ }^{\text {ns }}=$ not significant; Means followed by the same letter in the column do not differ statistically according to Duncan's test $(\mathrm{p} \leq 0.05)$.

Regarding the number of tillers, Salantur et al. (2006) pointed out this yield component as the main responsible for increasing wheat productivity in fields with not-established population of Azospirillum spp. However, differently from these authors as well as to Fukami et al. (2016), in the present work any yield promotion can be attributed to tillering, as NTP data was not significant (Table 2). Nunes et al. (2015) and Ferreira et al. (2017) also did not reported any increase of NTP as result of inoculation and attributed the crop lack of response to Azospirillum spp. to the soil high $\mathrm{N}$ availability prior sowing.

In this work, SDW data obtained from the in-furrow (treatment 6) and foliar (treatment 8) applications at the dose of $300 \mathrm{~mL} \mathrm{ha}^{-1}$ provided similar values to treatment 3 , in which full $\mathrm{N}$ mineral fertilization was applied (Table 2). However, it is important to point out that our SDW results were not conclusive, as, at the same time, treatments 6 and 8 showed comparable values to the others, including the control. Therefore, our SDW results reinforce those of Fukami et al. (2016) and Hungria et al. (2010), who also reported no increase in wheat shoot biomass triggered by inoculation. In fact, diazotrophic bacteria have shown to be more efficient at stimulating shoot growth in soils poor in N (Salantur et al., 2006), since a high availability of this element can impair the activity of nitrogenase, the enzyme responsible for reducing atmospheric $\mathrm{N}$ into biologically available compounds (Fukami et al., 2018). In this sense, it is likely to presume that in our work the remaining or native bacterial population coupled with soybean residues from precedent seasons may have constituted an available $\mathrm{N}$ source to plants, which may have neutralized or even inhibited the bacterial stimulation of SDW, NTP, NGS, HW and TSM.

Comparing standard seed-inoculation to the in-furrow and foliar ones, Fukami et al. (2016) concluded that the two latter methods were more promising to increase Azospirillum abundance and N-content in plant tissues. Nonetheless, our NCDS results did not corroborate their outcome, as herein any dose or method of inoculation affected leaves $\mathrm{N}$ content (Table 2). Other than that, our results support Nunes et al. (2015), since NCDS clearly responded to $\mathrm{N}$ fertilization. Plant-bacteria symbiosis is a species-specific process (Drogue et al., 2014) that, in the case of wheat inoculation with Azospirillum, has further shown to be genotype-dependent. Therefore, besides the soil $\mathrm{N}$ availability provided by the organic matter of soybean, it cannot be discarded the hypothesis that varietal differences could additionally have contributed to the NCDS results found in this work (Kaiz et al., 2016). 
Another important aspect related to $\mathrm{N}$ content in wheat is the protein concentration of grains, since this is a key technological factor in flour quality (Cazetta et al., 2008). In this work, full supply of mineral N (treatment 3) presented the highest value of NCG (Table 2), while intermediate data were observed under the inoculant dose of $300 \mathrm{~mL} \mathrm{ha}{ }^{-1}$ in both in-furrow and foliar applications (treatments 6 and 8, respectively). Such similar performance was also observed concerning the productivity, as only the treatment based on entire mineral fertilization provided the highest CY value (Table 2).

Unlike what we observed in this work, Hungria et al. (2010), Fukami et al. (2016), and Marks et al. (2015) reported that $\mathrm{N}$ management based on mineral fertilization coupled with standard (seed) or foliar inoculations provided wheat yields equivalent to those obtained under the full $\mathrm{N}$ recommendation. However, it is worthwhile mentioning that differently from those mentioned authors, in this work the $\mathrm{N}$ fertilizer rate was $25 \%$ lower. Despite that, our results confirm the potential of foliar Azospirillum application to partially contribute with the input of $\mathrm{N}$ to plants.

\section{Conclusion}

The supply of the half dose of mineral $\mathrm{N}$ associated to foliar inoculation with Azospirillum at the dose of $300 \mathrm{~mL}$ $\mathrm{ha}^{-1}$ provided positive results on wheat yield. However, the full mineral $\mathrm{N}$ fertilization stood out as the best $\mathrm{N}$ fertilization management.

\section{Acknowledgements}

To Coordenação de Aperfeiçoamento de Pessoal de Nivel Superior - CAPES for the scholarships awarded to the first author as well as for providing the resources for research development.

\section{References}

AOAC (Association of Official Analytical Chemistry). (2010). Official methods of analysis of the Association of Official Analytical Chemistry (p. 1115). Washington, D.C.: Association of Official Analytical Chemistry.

Brasil, Ministério da Agricultura, Pecuária e Abastecimento. (2009). Regras para análise de sementes (p. 399). Brasília: MAPA/ACS.

Campo, J. R., Araújo, R. S., \& Hungria, M. (2009). Nitrogen fixation with the soybean crop in Brazil: compatibility between sedd treatment with fungicides and bradyrhizobial inoculants. Symbiosis, 48(1/3), 154-163. https://doi.org/10.1007/BF03179994

Cazetta, D. A., Asieri Filho, D., Arf, O., \& Germani, R. (2008). Qualidade industrial de cultivares de trigo e triticale submetidos à adubação nitrogenada no sistema de plantio direto. Bragantia, 67(7), 41-50. https://doi.org/10.1590/S0006-87052008000300024

CONAB (Companhia Nacional de Abastecimento). (2019a). Acompanhamento da safra brasileira de grãos (Safra 2018/19, p. 119). Brasília: Conab. Retrieved from https://www.conab.gov.br/info...da.../25773_3bb6 47376d4be87c19609db735f132ff

CONAB (Companhia Nacional de Abastecimento). (2019b). Acompanhamento da safra brasileira de cana-de-açúcar (Safra 2019/2020-Primeiro Levantamento, p. 58). Brasília: Conab. Retrieved from https://www.conab.gov.br/info-agro/safras/cana/boletim-dasafra-de-cana-de-acucar

Cunha, G. R., \& Caierão, E. (2014). Informações técnicas para trigo e triticale (Safra 2015, p. 229). VIII Reunião da Comissão Brasileira de Pesquisa de Trigo e Triticale, Embrapa, Brasília.

Deuner, S., Nascimento, R., Ferreira, L. S., Badinelli, P. G., \& Kerber, R. S. (2008). Adubação foliar e via solo de nitrogênio em plantas de milho em fase inicial de desenvolvimento. Revista Ciência e Agrotecnologia, 32(5), 1359-1365. https://doi.org/10.1590/S1413-70542008000500001

Dobbelaere, S., Croonenborghs, A., Trys, A., Vande Broek, A., \& Vanderleyden, J. (1999). Phytostimulatory effect of Azospirillum brasilense wild type and mutant strains altered in IAA production on wheat. Plant and Soil, 212(2), 155-164. https://doi.org/10.1023/A:1004658000815

Döbereiner, J., \& Day, J. M. (1976). Associative symbioses in tropical grasses: Characterization of microorganisms and dinitrogen-fixing sites (pp. 518-538). International Symposium on Nitrogen Fixation, 1, Washington. Proceedings... Washington, D.C.: Washington State University Press.

Drogue, B., Sanguin, H., Chamam, A., Mozar, M., Llauro, C., Panaud, O., ... Wisniewski-Dyé, F. (2014). Plant root transcriptome profiling reveals a strain-dependent response during Azospirillum rice cooperation. Frontiers in Plant Science, 5, 607. https://doi.org/10.3389/fpls.2014.00607 
EMBRAPA (Empresa Brasileira de Pesquisa Agropecuária). (2018). Sistema brasileiro de classificação de solos (p. 353). Brasília: Embrapa.

Ferreira, J. P., Nunes, R. F., Silva, R. B., Dal Bem, E. A., Garcia, D. P., Sabundjian, M. T., \& de Souza, F. M. L. (2017). Azospirillum brasilense via foliar e doses de nitrogênio em cobertura na cultura do trigo na região de Itapeva-SP. Revista Brasileira de Engenharia de Biossistemas, 11(2), 154-163. https://doi.org/10.18011/ bioeng2017v11n2p154-163

Fukami, J., Cerezini, P., \& Hungria, M. (2018). Azospirillum: Benefits that go far beyond biological nitrogen fixation. AMB Express, 8(1), 73. https://doi.org/10.1186/s13568-018-0608-1

Fukami, J., Nogueira, M. A., Araujo, R. S., \& Hungria, M. (2016). Accessing inoculation methods of maize and wheat with Azospirillum brasilense. AMB Express, 6(1), 3. https://doi.org/10.1186/s13568-015-0171-y

Hungria, M., Campo, R. J., Souza, E. M. S., \& Pedrosa, F. O. (2010). Inoculation with selected strains of Azospirillum brasilense and A. lipoferum improves yields of maize and wheat in Brazil. Plant and Soil, 331(1-2), 413-425. https://doi.org/10.1007/s11104-009-0262-0

Hungria, M., Loureiro, M. F., Mendes, I. C., Campo, R. J., \& Graham, P. H. (2005). Inoculant preparation, production and application. Nitrogen fixation in agriculture, forestry, ecology, and the environment ( $\mathrm{pp}$. 223-253). Springer, Dordrecht. https://doi.org/10.1007/1-4020-3544-6_11

IAPAR (Instituto Agronômico do Paraná). (2018). Estações meteorológicas. Retrieved from http://www.iapar.br/ arquivos/Image/monitoramento/Medias_Historicas/Paranavai.htm

Kazi, N., Deaker, R., Wilson, N., Muhammad, K., \& Trethowan, R. (2016). The response of wheat genotypes to inoculation with Azospirillum brasilense in the field. Field Crops Research, 196, 368-378. https://doi.org/10.1016/j.fcr.2016.07.012

Marks, B. B., Megías, M., Ollero, F. J., Nogueira, M. A., Araujo, R. S., \& Hungria, M. (2015). Maize growth promotion by inoculation with Azospirillum brasilense and metabolites of Rhizobium tropici enriched on lipo-chitooligosaccharides (LCOs). AMB Express, 5(1), 71. https://doi.org/10.1186/s13568-015-0154-z

Nunes, P. H. M. P., Aquino, L. A., Dos Santos, L. P. D., Xavier, F. O., Dezordi, L. R., \& Assunção, N. S. (2015). Produtividade do trigo irrigado submetido à aplicação de nitrogênio e à inoculação com Azospirillum brasilense. Revista Brasileira de Ciência do Solo, 39(4), 174-182. https://doi.org/10.1590/01000683 rbcs20150354

Salantur, A., Ozturk, A., \& Akten, S. (2006). Growth and yield response of spring wheat (Triticum aestivum L.) to inoculation with rhizobacteria. Plant, Soil and Environment, 52(3), 111. https://doi.org/10.17221/ 3354-PSE

SAS (Statistical Analysis System). (2014). SAS ${ }^{\circledR}$ University Edition. Cary: SAS Institute Inc.

\section{Copyrights}

Copyright for this article is retained by the author(s), with first publication rights granted to the journal.

This is an open-access article distributed under the terms and conditions of the Creative Commons Attribution license (http://creativecommons.org/licenses/by/4.0/). 